2018-01

The relationship between quality defects

and the thermal performance of

buildings

\author{
Alencastro, J \\ http://hdl.handle.net/10026.1/10031
}

10.1016/j.rser.2017.08.029

Renewable and Sustainable Energy Reviews

Elsevier BV

All content in PEARL is protected by copyright law. Author manuscripts are made available in accordance with publisher policies. Please cite only the published version using the details provided on the item record or document. In the absence of an open licence (e.g. Creative Commons), permissions for further reuse of content should be sought from the publisher or author. 


\title{
The relationship between quality defects and the thermal performance of buildings
}

\author{
João Alencastro ${ }^{a^{*}}$, Alba Fuertes ${ }^{a}$, Pieter de Wilde ${ }^{\mathrm{a}}$ \\ a Department of Architecture and Built Environment, Plymouth University, Drake Circus, Plymouth, \\ Devon, PL4 8AA, United Kingdom
}

\begin{abstract}
The construction sector accounts for a significant portion of the total final energy use and carbon emissions worldwide. Despite efforts to reduce energy consumption through energy efficiency improvements in buildings, the measures proposed by the construction sector are falling short. Among several causes which lead buildings to perform differently to what was defined in the design stage, commonly referred to as the 'energy performance gap', the occurrence of quality defects has been acknowledged. This paper aims to identify through an in-depth literature review, quality defects which undermine the thermal performance of buildings by comparing the studies' findings with regard to defect characteristics and attributes; major causes and influencing factors; and their impact on the energy performance of construction projects. This review also aims to highlight areas where more research is needed if the expected thermal performance of buildings is to be achieved. Understanding the generation process and effects of defects on the energy efficiency of buildings can support the implementation of appropriate quality management systems in construction projects and thus contribute to the achievement of the intended energy performance targets.
\end{abstract}

Keywords: Thermal performance; building fabric, quality defects; construction defects.

\section{Introduction}

Construction is the largest energy consuming sector in the world. Buildings account for over $40 \%$ of the total final energy consumption and an equally significant source of carbon emissions [1, 2]. Policymakers and scholars have realised that only with significant reductions in the energy demand of buildings, provided by increased energy efficiency, it will be possible to reduce carbon emissions [3, 4].

The construction sector has made improvements towards increasing the energy efficiency of buildings by upgrading the thermal performance of the existing stock and building new low energy buildings [ 5 , $6]$. However, despite the efforts, recent studies indicate that the intended energy savings are falling short $[5,7,8]$.

According to research by the Carbon Trust [9] on 28 case studies in the United Kingdom, measured building energy consumption was up to five times higher than estimated at the design stage. Another study by Zero Carbon Hub [10] of 16 housing developments in the UK indicated that all the dwellings assessed presented a measured heat loss higher than predicted. This mismatch between the energy performance as predicted at design stage and as measured once the building is in operation is known as the energy performance gap [11-14]. 
The causes of the energy performance gap have been defined in the literature according to its root causes, such as design and construction processes, and operational issues $[9,11]$. At the design stage, the issues are closely related to the miscommunication among clients, design teams and builders when defining the building energy performance aspirations and the required strategies for implementation stage. Another important contributor are the discrepancies between simulated and actual building occupants' behaviour due to the impossibility to fully predict the buildings' future use and occupants' behaviour. [10,11, 12, 14]. At the construction stage, site management and workmanship have been acknowledged as possible causes of the gap. The buildings elements are often not in accordance with the design specification due to lack of information, skills or motivation. In addition, the occurrence of changing of orders by clients or material specifications by value engineering have the potential of compromising the performance attributes of the buildings components $[2,7,8,11,15,16]$. Finally, during the operational stage, the occupant behaviour is often cited as the major contributor to the energy performance gap. Moreover, the building energy management system can be particularly complex and unfriendly to use, thus affecting the operational energy use of the building $[3,8,9,11]$. Among this wide number of contributing factors to the energy performance gap [14] and related to the three stages of the building lifecycle, poor quality management and the occurrence of defects have been identified as important contributors $[2,8,11$, $15,16]$.

Whilst poor quality management and defects in construction projects are well-known problems [17, 18 ] and have been widely discussed in the literature, existing studies have mainly focused on the impact on projects' key performance indicators (e.g. time, cost, client satisfaction, etc.) [19]. To the authors' knowledge, there are few studies which identify and assess the impact of poor quality management and defects on the energy performance of buildings, in particular regarded to the thermal performance.

Within the context of energy and buildings, this paper provides a literature review of quality defects in the construction sector with the aim to identify those areas of knowledge that suggest the existence of a relationship between quality defects and poorer building thermal performance. The review combines the findings of previous studies to establish the defect characteristics and attributes; major causes and influencing factors; their impact on construction project performance, and finally, the effect on the thermal performance of buildings. The paper also highlights the areas where more research is needed if the intended thermal performance of buildings is to be achieved. It is hoped that this review will help researchers, construction associations and practitioners working on improving building energy performance or quality in construction by providing a detailed review of the most reported defects and their impact on construction projects.

\section{Definition of quality defect in construction}

In both academia and industry, different terms such as 'defect' (e.g. [20-22]), 'snag' (e.g. [22, 23]), 'fault' (e.g. [24]) and 'failure' (e.g. [25]) are used to describe imperfections on an element or an item 
that constitutes a building system. Although with a slight different meaning, the terms 'quality deviation' [25, 26] and 'non-conformance' [27] are also used.

Similarly, different definitions to describe the term defect exist. For example, Georgiou et al. [28] defines defect as a "shortcoming or falling short in the performance of a building element" or "a situation where one or more elements do not perform its/their intended functions". Watt [29] refers to defect as a "failing or shortcoming in the function, performance, statutory or user requirements of a building, and might manifest itself within the structure, fabric, services, or other facilities of the affected building".

Unfortunately, the lack of differentiation of these terms and definitions, and the interchangeable use between studies, have led to inaccurate identification of defects, quantification of the associated costs and definition of the most appropriate mitigation strategies [30]. For the purpose of this study, the term defect is defined based on Watt's definition [29]. However, it is worth mentioning that not all the studies included in this review defined the term defect in such an objective way.

\section{Previous studies investigating quality defects in construction}

This paper aims to provide a comprehensive state of the art on quality defects in construction. It provides an analysis of the literature in terms of previous research's findings related to the defects' characteristics and attributes; the major causes and influencing factors; and the consequences of defect occurrences on the project and building performance.

Table 1 classifies the reviewed studies by the year when the study was published, the country where the study took place, the building type (domestic or non-domestic), stage of the project when the data was collected (construction, handover, or post-handover), the method used to collect the data (author, third party, contractor, or building occupant), and the sample size (both number of projects involved and buildings/dwellings studied).

The majority of previous studies (79\%) focused on residential buildings. In Europe the studies explored domestic building projects located in Portugal [31], Spain [20, 21, 32-35], Sweden [36, 37], and UK $[9-11,13,15,18,22,23,29,38-56]$. Internationally, the domestic building projects studied were located in Australia [24, 28, 30, 57-61], China [62], Malaysia [63], Singapore [64-67], and United States (US) $[68,86]$.

A smaller number of studies (37\%) focused on non-domestic buildings. In Europe, the studies focused on commercial, educational, governmental and industrial buildings in Sweden [36, 37]; and commercial, educational, governmental, health, industrial and infrastructure projects in the UK [8, 9, $15,29,39,53,55,69]$. At an international level, there are studies investigating quality in commercial, educational, governmental and industrial facilities in Australia [59-61, 70]; commercial and infrastructure projects in Canada [71, 72]; governmental buildings in China [62]; infrastructure projects in Iran [73]; educational buildings in Nigeria [74]; commercial, health, industrial, infrastructure and 
governmental buildings in Singapore [64-67]; and commercial, governmental and industrial facilities in the US $[26,68,75]$.

Noteworthy, $24 \%$ of the studies analysed in this paper studied both domestic and non-domestic buildings and in $8 \%$ of the studies the building type analysed was not mentioned. The concentration of studies undertaken in residential buildings might be due to the fact that the residential building stock in Europe, for instance, corresponds to $75 \%$ of the total building stock [76]. In addition, the reasons and impacts of quality issues in domestic building are more tangible and representative. The nonresidential building stock comprises a more complex and heterogeneous sector compared to the residential sector and thus researchers' key findings tend to be less replicable $[15,76,77]$.

Quality defects are identified and collected by different stakeholders and through different methods depending on the stages of the building project. For example, during the construction process, quality defects are usually collected by the main contractor by means of internal quality inspections at different checkpoints in the programme of works, incoming material inspections, and internal and/or external audits. Once the construction is complete, quality issues may be identified as a result of building performance surveys by specialized consultants (e.g. thermographic survey of the building fabric and airtightness test), by both the contractor and the project client at the pre-commissioning stage prior to the practical completion of the works (normally 2 weeks before handing over the building), and by the project client and warranty providers at the final commissioning and handover, when the building is deemed completed and ready for occupation. At post-handover, when the building is occupied and operational, defects are normally gathered through client, owner or building occupants' complaints during the defects liability period, normally 12 months after handover in which the contractor is responsible for any defect occurring in the building.

In $47 \%$ of the studies reviewed, data was collected during the construction phase; $22 \%$, at handover, and $41 \%$, at post-handover. Some studies, however, collected data in more than one stage $(20 \%)$. For instance, Chong and Low [67] analysed data from both construction and post-handover stages to understand the different causal factors of visible and latent defects.

In respect to the data collection methods used, in $61 \%$ of the reviewed studies data was collected by the academics/researchers; $22 \%$ by a third party (insurance companies, warranty providers or independent inspection companies); $14 \%$ by constructions companies (non-conformances records); and $11 \%$ by the occupants through warranty claim forms. It is noteworthy that in only $12 \%$ of the studies the authors relied on more than one source of data. In $8 \%$ of the studies analysed, the data collection method could not be identified. Several authors claim that there are structural differences in regard to the perceived quality between end-users and trained professionals; and between contractors' building surveyors and independent inspectors [22, 50, 52]. For example, Sommerville et al. [52] studied the quantity of defects recorded in the post-handover stage in 600 residential units in the UK. The study suggested that independent inspectors working on behalf of the customer are more effective and accurate in identifying defects than the contractor. The authors stated that "this is of great concern and shows either lack of knowledge, awareness, and inexperience on behalf of the 
identifier or a lack of care and a poor attitude towards quality on behalf of the contractor" and therefore it is important to bear in mind the data collection method when comparing studies.

The building cases sample size varies from study to study. When data is collected by the researchers, sample size is generally smaller, ranging from 1 to 420 cases (e.g. housings units), and the focus relies on an in-depth analysis of the subject of the research. For instance, Johnston et al. [42] collected data from 3 dwellings and assessed the thermal performance of the buildings' fabric in comparison to their previous predictions. Love and Edwards [59] analysed data from 2 developments, with a total of 44 dwellings, to understand the impact of defects on costs and schedule overruns. Studies in which data is collected by third parties, construction companies' records and occupants' warranty claim forms provided bigger samples. Generally, these studies implemented a holistic approach towards defects' characteristics or causal factors to find replicable and representative findings. For example, llozor et al. [24] used data collected by an independent inspection company in 42,753 dwellings in order to establish the type of defects and the affected building elements providing an extensive overview of the housing sector in Victoria, Australia. 
Table 1. Summary of the literature on quality defects in construction projects

\begin{tabular}{|c|c|c|c|c|c|c|c|c|c|c|c|c|c|}
\hline \multirow[b]{2}{*}{ Author } & \multirow[b]{2}{*}{ Year } & \multirow[b]{2}{*}{ Country } & \multicolumn{2}{|c|}{ Building type } & \multicolumn{3}{|c|}{ Stage of data collection } & \multicolumn{4}{|c|}{ Data collection method } & \multicolumn{2}{|c|}{ Sample size } \\
\hline & & & Domestic & $\begin{array}{l}\text { Non- } \\
\text { domestic }\end{array}$ & $\begin{array}{l}\text { During } \\
\text { construction }\end{array}$ & Handover & $\begin{array}{l}\text { Post- } \\
\text { handover }\end{array}$ & Author & $\begin{array}{l}\text { Third } \\
\text { party }\end{array}$ & Contractor & Occupant & $\begin{array}{l}\text { No. of } \\
\text { projects }\end{array}$ & $\begin{array}{l}\text { No. of } \\
\text { subjects }\end{array}$ \\
\hline Aljassmi et al. [57] & 2014 & Australia & $\mathrm{X}$ & & & & $\mathrm{X}$ & & $x$ & & & 4 & - \\
\hline Love and Edwards [70] & 2012 & Australia & & $x$ & & & $\mathrm{x}$ & $\mathrm{x}$ & & & & & 23 \\
\hline Georgiou [58] & 2010 & Australia & $\mathrm{X}$ & & $\mathrm{x}$ & & $\mathrm{x}$ & & $\mathrm{x}$ & & & & 100 \\
\hline Mills et al. [30] & 2009 & Australia & $x$ & & & & $x$ & & & & $\mathrm{x}$ & - & - \\
\hline llozor et al. [24] & 2004 & Australia & $\mathrm{x}$ & & & & $\mathrm{x}$ & & $\mathrm{x}$ & & & & 42,753 \\
\hline Love and Edwardsa [78] & 2004 & Australia & - & - & - & - & - & & $\mathrm{x}$ & $x$ & & - & 161 \\
\hline Love and Edwardsb [59] & 2004 & Australia & $\mathrm{x}$ & $x$ & $x$ & & & $\mathrm{x}$ & & & & - & 44 \\
\hline Love $[60]$ & 2002 & Australia & $\mathrm{x}$ & $\mathrm{x}$ & & & $\mathrm{x}$ & & & $\mathrm{X}$ & & - & 161 \\
\hline Love and Li [61] & 2000 & Australia & $\mathrm{x}$ & $\mathrm{x}$ & $\mathrm{x}$ & & & $\mathrm{x}$ & & & & 2 & 44 \\
\hline Georgiou et al. [28] & 1999 & Australia & $\mathrm{x}$ & & & $\mathrm{x}$ & & & $\mathrm{x}$ & & & & 1,772 \\
\hline Battikha [71] & 2008 & Canada & & $\mathrm{x}$ & $\mathrm{x}$ & & & $\mathrm{x}$ & & & & 2 & 2 \\
\hline Fayek et al. [72] & 2004 & Canada & & $\mathrm{x}$ & $\mathrm{x}$ & & & $x$ & & & & 1 & 1 \\
\hline Palaneeswaran et al. [62] & 2007 & China & $x$ & $x$ & $x$ & & & $x$ & & & & 2 & 2 \\
\hline Kalamees [79] & 2007 & Estonia & $x$ & & & $\mathrm{x}$ & & $x$ & & & & - & 32 \\
\hline Aissani et al. [2] & 2016 & France & $x$ & $\mathrm{x}$ & & & $\mathrm{x}$ & $\mathrm{x}$ & & & & - & - \\
\hline Jafari and Love [73] & 2013 & Iran & & $\mathrm{x}$ & $\mathrm{x}$ & & & $\mathrm{x}$ & & $\mathrm{x}$ & & 1 & 1 \\
\hline Abdul-Rahman et al. [63] & 2014 & Malaysia & $\mathrm{x}$ & & & & $\mathrm{x}$ & $x$ & & & & - & 310 \\
\hline Ahzahar et al. [80] & 2011 & Malaysia & - & - & - & - & - & $\mathrm{x}$ & & & & - & 41 \\
\hline Aiyetan [81] & 2013 & Nigeria & - & - & - & - & - & $x$ & & & & - & 120 \\
\hline Oyewobi et al. [74] & 2011 & Nigeria & & $x$ & & & $\mathrm{x}$ & & $\mathrm{x}$ & $\mathrm{x}$ & $\mathrm{x}$ & 25 & 25 \\
\hline Silvestre and de Brito [31] & 2011 & Portugal & - & - & & & $\mathrm{x}$ & $x$ & & & & - & 37 \\
\hline Hwang et al. [64] & 2014 & Singapore & $x$ & $\mathrm{x}$ & - & - & - & $\mathrm{x}$ & $\mathrm{x}$ & $x$ & $\mathrm{x}$ & 381 & - \\
\hline Hwang et al. [65] & 2009 & Singapore & $\mathrm{x}$ & $\mathrm{x}$ & - & - & - & & $\mathrm{x}$ & & & 359 & - \\
\hline Chong and Low [66] & 2006 & Singapore & $x$ & $\mathrm{x}$ & $\mathrm{x}$ & & $\mathrm{x}$ & & $\mathrm{x}$ & & & 74 & - \\
\hline Chong and Low [67] & 2005 & Singapore & $\mathrm{x}$ & $x$ & $x$ & & $\mathrm{x}$ & & $\mathrm{x}$ & & & 74 & - \\
\hline Forcada et al. [32] & 2015 & Spain & $\mathrm{x}$ & & $\mathrm{x}$ & $\mathrm{x}$ & $\mathrm{x}$ & & & $\mathrm{x}$ & $\mathrm{x}$ & 16 & 2,179 \\
\hline Forcada et al. [20] & 2014 & Spain & $\mathrm{x}$ & & $\mathrm{x}$ & & & & & $\mathrm{x}$ & & 68 & - \\
\hline Forcada et al. a [33] & 2013 & Spain & $\mathrm{x}$ & & & & $\mathrm{x}$ & & & & $\mathrm{x}$ & 7 & 533 \\
\hline Forcada et al. b [34] & 2013 & Spain & $\mathrm{x}$ & & & & $\mathrm{x}$ & & & & $\mathrm{x}$ & 7 & 533 \\
\hline Macarulla et al. [21] & 2013 & Spain & $\mathrm{x}$ & & $\mathrm{x}$ & & $\mathrm{x}$ & & & $\mathrm{x}$ & & 3 & 218 \\
\hline Forcada et al. [35] & 2012 & Spain & $x$ & & & & $\mathrm{x}$ & & & & $x$ & - & 95 \\
\hline Josephson et al. [36] & 2002 & Sweden & $\mathrm{x}$ & $\mathrm{x}$ & $\mathrm{x}$ & & & $\mathrm{x}$ & & & & 7 & - \\
\hline Josephson and Hammarlund [37] & 1999 & Sweden & $x$ & $\mathrm{x}$ & $\mathrm{x}$ & & & $\mathrm{x}$ & & & & 7 & - \\
\hline NEF [5] & 2016 & UK & $x$ & & $\mathrm{x}$ & $x$ & $x$ & & $x$ & & & 28 & \\
\hline Palmer et al. [7] & 2016 & UK & $\mathrm{x}$ & & $x$ & $\mathrm{x}$ & $x$ & $x$ & $\mathrm{x}$ & & & - & 76 \\
\hline van Dronkelaar et al. [82] & 2016 & UK & & $\mathrm{x}$ & $\mathrm{x}$ & $x$ & $\mathrm{x}$ & & $\mathrm{x}$ & & & - & 62 \\
\hline Zero Carbon Hub [83] & 2016 & UK & $\mathrm{x}$ & & $\mathrm{x}$ & & & $\mathrm{x}$ & & & & - & - \\
\hline Hansford [38] & 2015 & UK & $\mathrm{x}$ & & $x$ & $x$ & $x$ & $x$ & & & & - & - \\
\hline Davis et al. [39] & 2015 & UK & $\mathrm{x}$ & $\mathrm{x}$ & - & - & - & - & - & - & - & - & - \\
\hline Johnston et al. [40] & 2015 & UK & $\mathrm{x}$ & & & $\mathrm{x}$ & & $\mathrm{x}$ & & & & & 25 \\
\hline
\end{tabular}




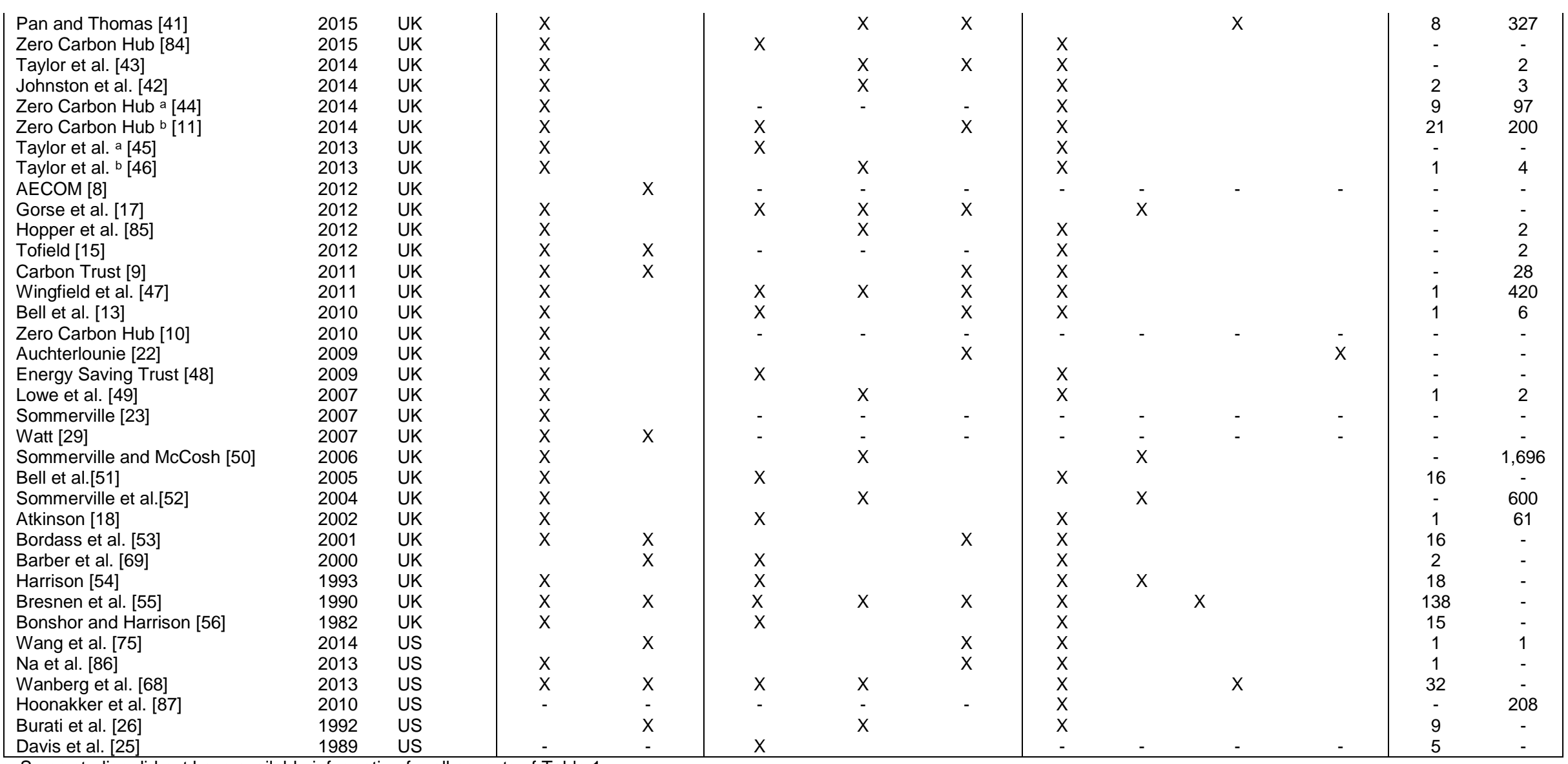

Note: Some studies did not have available information for all aspects of Table 1. 


\section{Quality defects in construction projects}

Different approaches have been adopted in previous studies to identify and understand defect occurrences, their causes and related impacts on the construction industry. Whilst there are authors focusing on quality defects occurring on specific building elements [2, 31, 38, 43, 45, 46, 48, 49], such as the insulation layer applied on a building's façade [2, 38], others focus on the building as a whole $[20,21,24,28,30,32-37,41,44,47,51,53,54,56,58,61,63,66,67,72]$.

Regardless of the scope of the analysis, the majority of the studies reviewed rely on a defect classification method which allows a categorisation of the defects based on their attributes, causes or related impacts [29]. The definition of an effective classification system of quality defects has been acknowledged as being a challenging task, as it may vary depending on the needs and aims of each research analysis, as well as the project peculiarities in relation to specific local building culture and technology deployed; managerial practices; and weather conditions which might influence the generation of defects [21, 63].

The following subsections provide a synthesis of the findings in the literature according to: (i) defect attributes; (ii) the defects' major causes and influencing factors; and (iii) the impacts of these defects on the project performance indicators as well as the building thermal performance.

\subsection{Defect attributes}

Previous studies analyse the defects by means of the following attributes: (i) defect type; (ii) affected building element; (iii) location in the building where the defect was manifested; and (iv) the trade or subcontractor involved in the defect occurrence. A synthesis of the quality defect attributes most commonly mentioned in the literature is provided in Table 2, along with the list of studies which indicated these findings. 
Table 2. Summary of quality defect attributes in construction projects

\begin{tabular}{|c|c|c|}
\hline Defect attributes & Most agreed findings & Previous studies \\
\hline Defect types & $\begin{array}{l}\text { Incorrect installation } \\
\text { Missing item } \\
\text { Surface appearance / Cracking on plaster } \\
\text { Gaps in the buildings' fabric / Cracking on } \\
\text { external walls / Poor installation of } \\
\text { insulation elements }\end{array}$ & $\begin{array}{l}{[2,5,17,20,21,24,28-34,41,44,47,51,53,} \\
54,58,62,63,66,67,71,79,80,83-86]\end{array}$ \\
\hline $\begin{array}{l}\text { Number of } \\
\text { defects per } \\
\text { housing unit }\end{array}$ & $\begin{array}{l}2.29-28.3 \text { average number of defects } \\
\text { per housing unit }\end{array}$ & {$[28,35,41,50]$} \\
\hline $\begin{array}{l}\text { Affected } \\
\text { building element }\end{array}$ & $\begin{array}{l}\text { External walls } \\
\text { Partitions } \\
\text { Closure components (doors and } \\
\text { windows) } \\
\text { Floors } \\
\text { Roofs }\end{array}$ & $\begin{array}{l}{[2,18,29,30,32,34,35,44,47,51,53,54,} \\
56,62,63,66,67,71,83-86]\end{array}$ \\
\hline $\begin{array}{l}\text { Location in the } \\
\text { building }\end{array}$ & $\begin{array}{l}\text { Rooms/bedroom } \\
\text { Bathroom } \\
\text { Kitchen } \\
\text { Lounge/Hall/Corridor } \\
\text { External doors } \\
\text { Building envelope (façade, roof and } \\
\text { structure) }\end{array}$ & {$[20,34,35,41,79,85]$} \\
\hline $\begin{array}{l}\text { Trade or } \\
\text { subcontractor } \\
\text { involved }\end{array}$ & $\begin{array}{l}\text { Plumbing } \\
\text { Carpentry/door and window closures } \\
\text { Brickwork / Partitions and enclosures } \\
\text { Structure }\end{array}$ & {$[20,28,32,34,62,71]$} \\
\hline
\end{tabular}

The definition of a defect taxonomy has been extensively explored with the purpose to establish a comprehensive and standardised list of defects to be used by construction companies and researchers during data collection and analysis [20, 21, 24, 28-34, 41, 54, 58, 63, 66, 67, 80].

Forcada et al. [20] established a classification system for residential building projects in Spain consisting of 12 types of defects in 68 housing developments: affected functionality; detachment; flatness and levelness; incorrect installation; misalignment; missing; others; soiled; stability/movement; surface appearance; tolerance error and water problems. The authors found that incorrect installation was the most recurrent type of defect during the construction stage, accounting for $24 \%$ of the occurrences. According to the authors, incorrect installation includes "materials, elements or items incorrectly positioned, or those that do not satisfy project specifications or do not have the adequate characteristics".

Similarly, Macarulla et al. [21] identified 15 different defect types, including: affected functionality; inappropriate installation; biological action; broken/deteriorated; chemical action; detachment; soiled; flatness and levelness; misaligned; missing; stability/movement; surface appearance; water problems; tolerance errors and others. Using this classification system, the authors compared the defect types identified in the construction and post-handover stages of 3 projects (218 housing units) in Spain and concluded that whilst the most recurrent type of defect during the construction stage was inappropriate installation (with a frequency of $32 \%$ ), at post-handover, the most observed type of defect was missing item or task, accounting for $55 \%$ of the occurrences. Similarly, Forcada et al. [33, 
34] also concluded that the most frequent type of defect collected at post-handover was missing item or task, appearing in $37 \%$ of the cases in seven Spanish housing schemes.

Georgiou [58] classified the defects according to the categories: cracking; damp; drainage; external leaks; incomplete; internal leaks; miscellaneous; no defects; regulations; structure adequacy; water hammer; window sill gap and workmanship. The author analysed the quality defects observed during the construction and post-handover stages of 100 domestic building projects in Australia and concluded that workmanship and incomplete were the most frequent defects, accounting for $40 \%$ and $20 \%$ of the occurrences, respectively. Noteworthy, the definition of the term workmanship used by the author suggests the same defect nature as inappropriate installation or incorrect installation used by other authors [20, 21], corroborating their findings.

Chong and Low [66] proposed a defect classification system focused on the main building elements, including: internal walls; external walls; floor; doors; windows; plumbing and sanitary defects; roofs; mechanical and electrical and ceilings. For each building element, different defect types were identified. The authors analysed data from 74 domestic and non-domestic buildings in Singapore and identified that one of the most recurrent defects was plaster crack on walls and partitions, accounting for $37 \%$ of the defects.

Similarly, Abdul-Rahman et al. [63] identified a vast list of defects, totalling 25 different anomalies, which the most frequent included: cracking in external walls; failure of the water supply system; dampness to concrete walls and leakage of pipes. The authors state that cracking in external walls is the major defect occurrence in 310 affordable housing units in Malaysia.

In line with the previous studies, Forcada et al. [32] found that surface appearance was the most recurrent defect, accounted for $64 \%$ of defects collected at handover in 2,179 Spanish housing units.

Others authors like Bordass et al. [53], Bell et al. [51] and Wingfield et al. [47] focused on quality defects affecting building thermal performance and found out that the most common defects were related to gaps in the buildings' fabric and poor installation of insulation elements. Several types of defects were identified in the studies including: missing cavity closers; gaps in insulation at jambs and sills; inadequate sealing, no insulation behind cavity tray; discontinuity of insulation layer; gaps between floor and walls junctions, structural thermal bridging; services thermal bridging; punctured or missing vapour/air barrier; services penetration without sealing; malfunction in mechanical ventilation and MVHR devices.

Undoubtedly the number of defects in a project is one of the most important factors to measure quality in construction and it has been widely used as a key indicator by the building industry [22, 54]. According to Georgiou et al. [28] who studied records from 1,772 houses in Australia, the number of defects per dwelling built by owner builders ranges from 0 to 21 , with an average of 2.73 per house. While dwellings built by registered builders presented a range from 0 to 16 defects per house, with a slightly lower average of 2.29. Also exploring a large sample of 1,697 houses in the UK, Sommerville and McCosh [50] found a range of defects per house between 1 and 389 occurrences. The average 
number of defects per house was 44 however the study identified a considerable variation of number of defects between dwellings. Pan and Thomas [41] compared defects from houses and flats and concluded that in houses the number of defects ranged from 0 to 47 per dwellings with an average of 10.6, whereas in flats the range of occurrences was between 0 and 20 and an average of 6.9. Using a similar approach, Forcada et al. [35] found that the averages of defects per detached house and per flat were 21 and 28.3 .

The wide variation amongst the number of defects could be explained by differences in the building type, the construction method used, the management procedures undertaken, and the data collection methods used.

Quality defects are also analysed in the literature according to the building element affected. The majority of studies in the review [20,32, 35, 54, 56, 63] suggest that walls, partitions and closure components (doors and windows) are the building elements where defects are more likely to occur. Forcada et al. [35] stated that $43 \%$ of the defects studied were detected in partition and closure elements: $14 \%$ affecting internal walls, $15 \%$ found on doors and $14 \%$ on windows. Similarly, Forcada et al. [32] analysed a different dataset and found that internal walls accounted for $60 \%$ of the occurrences. Abdul-Rahman et al. [63] measured the frequency of defect occurrences on specific building elements and concluded that external walls had the highest manifestation of defects. Chong and Low $[66,67]$ found that defects are most likely to occur on floors, accounting for $17 \%$ of the affected elements. Differently, Mills [30] stated that roofs are the building element where more quality defects occurred (10\%).

The location or area in the building where defects are observed is another attribute used to analyse, plan and improve quality assurance in building projects. Forcada et al. [34, 35] concluded that the top five areas affected in residential units in Spain are: rooms/bedrooms (21\% - 22\%); bathrooms (17\%); kitchens (15\%); lounge (11\%) and hall/corridor (7\% - 8\%). Pan and Thomas [41] determined that most recurrent locations of defects manifestation in their study in the UK are: kitchens (15\%), bathrooms (14\%), external doors (10\%) and building envelope (9\%). Contrary to the previous studies where locations correspond mostly to internal areas, Forcada et al. [20] identified that general accounted for $54 \%$ of the locations involved in defect occurrences, followed by exterior areas $(10 \%)$. According to the authors' definition, general is a category of location which is related to the building's envelope, including façade, roof and structure.

Although less frequently, some authors also analyse the defect occurrences based on the trades and subcontractors involved. According to Georgiou et al. [28], the trade most involved in defects generation is plumbing, which appeared to be responsible for up to $26 \%$ of the occurrences. This was followed by carpentry (23\%), brickwork (15\%), plasterer (10\%), finishes (10\%), miscellaneous $(8 \%)$, external works $(6 \%)$ and electrical $(2 \%)$. Other trades commonly identified in the literature are those responsible for partitions and enclosures (51\%) [32], structure (29\%) [20] and door and windows closures (28\%) [34]. 


\subsection{Major causes and influencing factors}

According to Egan [77], a 20\% annual reduction in the number of defect occurrences at handover would be necessary to assure sustained improvement in buildings' quality. In order to fulfil this objective, it is vital not only to define, quantify and classify quality issues but to identify the root causes and influencing factors that lead to defects [70-72].

Different approaches to analyse and classify the major causes of defects and influencing factors in construction projects have been used in the literature $[25,26,28,50,58]$. Table 3 presents the findings grouped by major causes and influencing factors.

Table 3. Summary of the major causes of defects and influencing factors in construction projects

\begin{tabular}{lll}
\hline $\begin{array}{l}\text { Causes and } \\
\text { influencing factors }\end{array}$ & Most agreed findings & Previous studies \\
\hline Origin of defects & Change, error, omission or damage & $\begin{array}{l}{[2,7,17,18,26,31,33,37,38,59,61,62,} \\
65,69-73,80,82]\end{array}$ \\
& & \\
\hline Sources of defects & $\begin{array}{l}\text { Workmanship, design, management, } \\
\text { machinery, material or lack of protection }\end{array}$ & $\begin{array}{l}{[2,5,7,11,15,17,18,23,26,29,31,33,} \\
36-38,44,47,53-57,59,61,62,64-67,69, \\
\\
\text { of already installed items }\end{array}$ \\
\hline Size of building & Number of bedrooms in dwellings & {$[41,53,75,79-82,86]$} \\
\hline Building type & Flat / House & {$[30,78]$} \\
\hline Construction method & Masonry / Timber frame & {$[41]$} \\
\hline
\end{tabular}

Note: Highlighted in italics, those causes and influencing factors with a potential effect on the building energy performance

Origin and source are intimately related when it comes to defect occurrences. Whilst the origin is deemed to be the act by which a defect is generated, the source is considered to be the actor or the activity involved in the defect occurrence, including workmanship, design, management, machinery, material or lack of protection of already installed items $[2,65,72,73,75]$.

Previous studies have identified change, error, omission or damage as the origin of defects $[33,61$, $69,70]$. Change is a directed action of modifying the currently defined requirements and may include the design, construction process, existing scope of contract, plans and specification or operational capability of the building. According to Love and Li [61], changes in the design are responsible for $54 \%$ of the defects costs. Similarly, Fayek et al. [72] suggest that changes and reviews in design and engineering are responsible for $55 \%$ of the number of defects occurrences and $62 \%$ of the rework costs. Noteworthy, in both studies the cases analysed are facilities of highly complex engineering requirements such as offshore projects and mining facility. Therefore, it is reasonable to assume that changes in the design are more likely to occur.

The term error is understood as any activity or a building element which is designed, manufactured, performed or installed incorrectly, resulting in the mismatch of the previous requirements. Barber et al. [69] estimates that $50 \%$ of the defects resulted from design errors. Burati et al. [26] state that design errors originated $30 \%$ and $24 \%$ of defects' in new projects and retrofits, respectively. Similarly, Silvestre and de Brito [31] claim that design errors are responsible for $60 \%$ of the anomalies in 
facades of buildings. With slightly different findings, Love and Li [61] and Josephson et al. [36] concluded that defects (55\% of the recorded occurrences) originated from errors during the construction stage related to poor workmanship.

The term omission relates to an activity or a building element which has been left out during the design, the manufacturing or the construction process. According to Forcada et al. [33], omission and workmanship are responsible for $42 \%$ of the origins and $64 \%$ of the sources of defects collected at the posthandover stage in the housing sector in Spain.

Finally, damage is defined as a physical harm affecting a building element in terms of usefulness or expected operational standards. Although this category does not stand as one of the most frequent origins of defects it still has an important contribution towards the resulting impacts of quality issues. For instance, Forcada et al. [33] and Love and Li [61] suggest that damage is responsible for $18 \%$ and $23 \%$ of defects, respectively, and are strictly related to workmanship and management.

In addition, Josephson and Hammarlund [37] suggest five other categories, including knowledge, information, motivation, stress and risk. The study suggests that $50 \%$ of defects were generated due to lack of motivation and manifested through forgetfulness and carelessness.

Atkinson [18] concluded that management, including poor formal communication and lack of closer supervision by site and design managers, is the most important source of defects, responsible for $63 \%$ of the defects. Similarly, other authors $[59,62,71,73,81]$ claim that poor planning, poor supervision, inadequate inspection and checking procedures and lack of quality focus are the underlying factors of defects.

The relationship between defect occurrences and particular building characteristics has also been explored by previous studies. Sommerville and McCosh [50], Pan and Thomas [41] and Sommerville et al. [52] identified a positive correlation between the number of defects and number of bedrooms in dwellings. However, the correlation between the floor area of the building and the number of defects in projects other than housing has not been confirmed by previous studies.

Pan and Thomas [41] and Forcada et al. [35] analysed the possible correlation between the number of defects and building type in the housing sector. Although both studies provided a positive correlation validated by statistical analysis their findings are different. Whilst Pan and Thomas [41] determined that the mean defects per dwelling are higher in houses (10.6) rather than in flats (6.88); Forcada et al. [35] claim that the mean number of defects per flat (28.3) is higher than in detached houses (21). The different findings might be explained by the distinct data collection methods used in the two studies. Pan and Thomas [41] used data collected by the construction company itself, while Forcada et al. [35] analysed data from occupant complaint forms.

Moreover, in regard to the correlation between the number of defects and the build method, Pan and Thomas [41] found that the average number of defects reported in houses built using masonry 
methods (10.22) was lower than houses built using timber frame methods (11.26). However, such a difference was observed not to be statistically significant.

\subsection{Impact of quality defects on construction projects performance}

The impact of quality defects on construction project performance can be synthesised in the following categories: (i) project cost; (ii) project programme; (iii) customer satisfaction; (iv) industry reputation; and $(v)$ health and safety. Table 4 provides a list of authors studying these relationships.

Table 4. Summary of the perceived impact of quality defects on construction project performance

\begin{tabular}{lll}
\hline $\begin{array}{l}\text { Project performance } \\
\text { aspects }\end{array}$ & Most agreed findings & Previous studies \\
\hline Cost & $\begin{array}{l}\text { The budget overruns due to defects } \\
\text { rectification range from } 3.23 \% \text { to } 23 \% .\end{array}$ & $\begin{array}{l}{[25,26,30,36,37,39,55,59-62,} \\
64,65,69,72-74,78]\end{array}$ \\
\hline Programme & $\begin{array}{l}\text { The programme overruns due to defects } \\
\text { rectification reach } 7.1 \% \text { to } 20.7 \% .\end{array}$ & {$[36,39,55,61,64,69,74,78]$} \\
& $\begin{array}{l}\text { The correlation between defects occurrences } \\
\text { and customer satisfaction is well established. }\end{array}$ & {$[15,22,32,35,39,41,55,87]$} \\
\hline Customer satisfaction & $\begin{array}{l}\text { The impact of defects occurrences on } \\
\text { Industry reputation }\end{array}$ & $\begin{array}{l}\text { construction companies' reputation is } \\
\text { identified. }\end{array}$ \\
\hline Health and safety & $\begin{array}{l}\text { The correlation between defects occurrences } \\
\text { and lower health and safety levels is well } \\
\text { established. }\end{array}$ & {$[29,68,78,87]$} \\
& & \\
\hline
\end{tabular}

The relationship between quality, project programme and cost has been the subject of extensive research. The cost associated with quality defects, i.e. the cost of rework, has been approached differently in previous research. While some studies solely determine the direct costs associated with defect rectification, such as extra material and workforce expenditures [25, 26, 36, 37, 59, 62, 65, 73, 74], others combine the direct and the indirect costs, which also include costs such as overheads, accommodation and subsistence costs [30, 39, 55, 60, 61, 72, 78]. In addition, while some studies present the rework costs as a percentage of the projects' contract value $[25,39,55,59-62,69,73,74$, 78], others calculate them as a percentage of the projects' construction costs [30, 36, 37, 65, 72]. Love [60] studied 161 domestic and non-domestic Australian projects and concluded that the average direct and indirect costs of rework were, respectively, $6.4 \%$ and $5.62 \%$ of the projects original contract value, and contributed to $52 \%$ of the projects total cost growth. Similar results were found by Barber et al. [69], who studied two non-domestic projects in the UK and concluded that the direct and indirect defects costs were $6.6 \%$ and $3.6 \%$ respectively. However, these costs would rise to $16 \%$ and $23 \%$ when adding the delay costs, such as contract delay fines. Josephson and Hammarlund [37] analysed the cost of rework in 6 domestic and non-domestic building projects in Sweden and concluded that defects direct costs can reach up to $9.4 \%$ of the production costs. When considering the construction errors only (not including rework caused by design changes), these costs contributed to cost overruns of $4.4 \%$ and schedule overruns of $7.1 \%$ [36]. Moreover, Oyewobi [74] compared costs overruns associated with non-residential new build and retrofit building projects and found that the new build projects presented higher correction costs $(5.06 \%)$ than the retrofit projects $(3.23 \%)$. Differing from previous studies, Hwang et al. [65] concluded that rework costs rarely influenced the overall cost 
increase in projects with contract values greater than $\$ 100$ million. According to the authors, this might be explained by the fact that the large construction costs of these projects might make them relatively less sensitive to the direct rework costs.

Quality defects have also been identified as one of the causes for schedule overruns [36, 39, 78]. For instance, the 2015 UK Industry Performance Report [39] states that only $40 \%$ of the projects were completed on time, rework being one of the causes for the schedule overruns. Love and Edwards [78] suggest in a study undertaken in 161 construction projects in Australia that the mean schedule growth due to defects correction was $20.7 \%$. Josephson et al. [36] suggest in a study of domestic and nondomestic projects in Sweden that the schedules overrun due to defects were $7.1 \%$.

The relationship between quality defects, customer's satisfaction and industry reputation has also been acknowledged in previous research [15, 22, 32, 35, 39, 41, 50, 52, 55, 87]. Auchterlounie [22] found that $57 \%$ of 300 new UK houses studied partially failed or completely failed to meet the clients' expectations. The main reasons for the customer's dissatisfaction were related to finishing and aesthetics defects rather than technical defects, such as roofing, services, etc., which were expected to be previously checked by professionals and inspected by the warranty provider. Other examples of quality defects not properly addressed are described in Forcada et al. [32, 35]. The authors identified defects recorded during handover which had not been appropriately rectified and consequently resulted in customer complaints. Differing from previous studies, Davis et al. [39] and Bresnen et al. [55] found that the majority of customers, $81 \%$ and $87 \%$ respectively, were satisfied or very satisfied with the overall quality of the dwellings.

A smaller number of studies have also acknowledged a correlation between quality and health and safety. Hoonakker et al. [87] studied 208 contractors in the UK and concluded that in $71 \%$ of the cases the implementation of quality assurance procedures helped to improve on-site health and safety levels. Similarly, Wanberg et al. [68] studied 32 domestic and non-domestic projects in the US and concluded that the first-aid rate was positively correlated to the number of defects, suggesting that the lower the quality performance (i.e. the higher the number of defects), the higher the likelihood to experience health and safety incidents on-site. Love and Edwards [78] explained this relationship stating that as rework activities increase, safety may be compromised as the pressure to complete the project on time and in budget also increases.

\subsection{Impact of quality defects on building thermal performance}

Quality defects have also been acknowledged as having a negative impact on the buildings thermal performance resulting in a higher energy consumption. These defects can be grouped in three distinct categories: (i) design defects; (ii) implementation or workmanship defects during the construction stage; and (iii) lifetime defects. Table 5 provides the list of studies for each category and the most agreed findings. 
Table 5. Summary of the perceived impact of quality defects on building thermal performance

\begin{tabular}{lll}
\hline Defect categories & Most agreed findings & Previous studies \\
\hline Design defects & Lack of literacy among the project team & {$[5,7-11,13,15,17,38,44,47-49$,} \\
& Poor detailing & $51,53,75,82-84]$ \\
& Poor design change management & \\
& Thermal bridging issues not addressed & \\
& Buildability issues & \\
\hline Implementation or & Thermal bridging & {$[2,5,7,8,11,13,15,17,38,40,42-$} \\
workmanship defects & Air permeability & $47,51,75,79,82-86]$ \\
during the construction & Discontinuity of insulation layer & \\
stage & Gaps on vapour and air barriers & \\
\hline Lifetime defects & Sealing degradation & {$[2,7,47,79,82]$} \\
& Moisture retention & \\
& Materials lifespan & \\
\hline
\end{tabular}

According to Zero Carbon Hub [11, 44], during the design stage, there is a lack of focus and understanding on the implications of the design decisions on the building energy performance. Uncertainty in setting design parameters can lead to design mistakes and inaccuracy of materials' specification. This lack of awareness of the design team is likely to impact various aspects of the energy performance of buildings [82]. For instance, Palmer et al. [7] investigated the building project of $76 \mathrm{UK}$ homes and concluded that the lack of literacy of the design team towards energy related aspects, added to an uncoordinated approach of the different design disciplines, resulted in nonintended thermal bridges and buildability issues which increased the air permeability of the buildings' envelope. Similarly, Hansford [38] states that the building physics are not widely nor fully understood by design professionals, resulting in inadequate design solutions and poor detailing. The author investigated external wall insulation retrofit projects undertaken in UK dwellings and confirmed that the occurrence of design defects resulted in thermal bridging. Wingfield et al. [47] studied 420 new homes in the UK and suggested that unrecognized heat loss mechanisms during the design stage (air leakage and thermal bridging through party walls and other construction cavities) undermined the expected building thermal performance. Other authors [7, 48, 51] suggest that there are also design defects related to the quality and accuracy of the information embedded in construction drawings and details which can result in incorrect interpretation and unnecessary amendments by the team working on-site. If not addressed with the right knowledge, these misunderstandings can result in faulty construction details which affect the expected building energy performance. Design changes have also been identified as a contributing factor. Palmer [7], van Dronkelaar [82] and AECOM [8] agree that in both domestic and non-domestic sectors there is lack of a robust design change management system. The authors highlight that changes of specification are frequently motivated by value engineering, supplier's change or client's requests. Unfortunately, the impact of these changes on the original designed energy performance of the building is rarely assessed as part of the process.

According to AECOM [8] and Bordass et al. [53], the in-use energy consumption of a building can be severely affected by the quality of its construction, mainly due to defects in the building's envelope and services. Johnston et al. [40], for instance, measured the thermal properties of 25 new dwellings in the UK and concluded that the whole fabric U-value was 1.6 greater than predicted in the design stage, caused by discontinuity of the insulation panels, due to poor workmanship management. 
Similarly, Bell et al. [13] found that the overall heat loss in 6 new-build dwellings in the UK was $54 \%$ higher than predicted, even though high levels of insulation were used to minimize the space heating demand. The study also identified that the average air permeability measured was $133 \%$ higher than desired, contributing significantly to heat loss. Similarly, a study undertaken by Zero Carbon Hub [10] on 16 UK houses indicated the heat loss was higher than predicted in all the measured dwellings. Both studies claimed that poor quality during the buildings fabric installation was the main reason for the thermal bridging, thermal bypass and air permeability causing unexpected heat loss rates. Similarly, in the latest report on energy performance of social housing projects in the UK (28 housing development), the National Energy Foundation [5] found that $67 \%$ of the projects failed to achieve the intended thermal transmittance of the external walls, $89 \%$ did not meet the roof/ceiling U-values, and $54 \%$ of the cases failed to achieve the desired air tightness. The defects deemed responsible for this underperformance were related to lack of continuity of the insulation layers, thermal bridges and services penetrations in the fabric without effective sealing.

In an attempt to quantify the thermal conductivity losses caused by defects in the external wall insulation layer, Aissani et al. [2] assessed four common workmanship errors (groove, opening, crush and sheath passage) through experimental measurements under laboratory conditions and finite element modelling. The findings of the study suggested that flexible insulation materials (e.g. mineral wool) were more affected by defects than rigid panels and in those cases the thermal performance losses due to defects occurrences reached up to $40 \%$ in the measured zone ( $300 \times 300 \mathrm{~mm})$. Johnston et al. [42] compared the designed and in situ U-values obtained by heat flux measurements and co-heating tests in 3 dwellings in the UK and demonstrated that defects during the construction process affected the overall thermal performance. The most recurrent defects were lack of continuity of the insulation layer, gaps in the vapour and air control barriers and thermal bridging through window lintels. The findings of the study showed that the measured U-values of the fabric elements (i.e. external wall, ground floor and roof) deviate in different proportions from their relative designed targets, suggesting that different types of defects can be more or less harmful to the fabric's thermal performance.

In respect of the lifetime defects, Wingfield et al. [47] investigated 420 dwellings in the UK for over 6 years (from design to post-occupation evaluation) and established a correlation between the degradation of the buildings fabric overtime and the decline of the thermal performance of buildings. The results showed that air permeability of the dwellings increased overtime, in some cases up to $30 \%$. The reduction of the airtightness occurred due to drying, shrinkage and settlement mainly in the intermediate floor perimeters (sealing and barrier elements) but also in other constructions junctions (e.g. wall/windows interfaces), mostly in timber floors and on wooden elements (e.g. window sills). Palmer et al. [7] studied 76 UK homes and the results highlighted the concerning practice of "plugging" gaps in the building fabric with sealant after the construction completion, instead of addressing the air permeability defects with a long term solution. Similarly, Kalamees [79] investigated 32 detached houses in Estonia and concluded that the utilisation of materials with different lifespans or inadequate interfaces contributed to increase air permeability overtime. As a consequence, the 
increase of the air penetration and decay of the vapour and air control barriers promoted moisture retention in the insulation layer, and thus an increased building fabric thermal transmittance [47, 82]. Moreover, Aissani et al. [2] also claim that flexible insulating materials (e.g. mineral wool) tend to collapse over the years after installation when applied on a vertical surface. According to the study, a collapsed or crushed insulation panel at $0.5 \%$ of its total volume results in the loss of $12 \%$ of its initial performance.

\section{Discussion}

Within the context of energy and buildings, this paper provides a literature review of quality defects in the construction sector with the aim to identify those areas of knowledge that suggest the existence of a relationship between quality defects and poorer building thermal performance. The review combined the results of previous studies to establish the defect characteristics and attributes; major causes and influencing factors; their impact on construction project performance, and finally, the effect on the building thermal performance.

The review confirmed the negative effect that quality defects have on the buildings' thermal performance. However, the number of studies focused on this area is still limited and the specific defects affecting properties such as air tightness are not yet well established in terms of their attributes and possible causes. The review also demonstrated that there is an extensive body of research exploring construction quality, which findings suggest the existence of defects and possible causes that could have a direct impact on the thermal performance of the building. However, this relationship is not specifically addressed in the majority of studies. Wingfield [47] suggests that there is a "need for more extensive and real world research" in order to address proper measures to mitigate quality defects which undermine the ability of buildings to fulfil their in-use energy consumption expectations.

It is apparent from the previous studies that researchers and practitioners need to establish a standardised taxonomy for construction defects and their causes and origins to allow easier comparison between studies. The lack of methodology for defect classification has the potential to compromise the comparison of research findings or provide ambiguous results $[21,37,58]$. No specific taxonomy was observed in those studies investigating the defects affecting the building thermal performance. Instead, they use a more descriptive approach to define the specific defects and their impacts towards heat loss.

The review also showed that the methods used to gather quality defects data and the stage in the project when this data is collected, varied significantly between studies. The variety of methods and stakeholders involved in the collection process also introduces a certain level of uncertainty with regards to the data collected. As pointed out by some authors [22, 50,52], quality can be perceived differently between individuals (e.g. building occupants, trained professionals, contractors, building surveyors, and auditors) and therefore the data collection could be more orientated to one kind of 
defect (e.g. aesthetic and functional) and miss others (e.g. those less evident affecting the building performance).

The stage in the project when the data is collected is also of significant consideration, particularly when investigating those defects that might impact the building's thermal performance. Studies focusing on the handover and post-handover stages reported mostly aesthetic or functional defects, such as affected functionality of building elements, detachment, flatness and levelness issues, and surface appearance [20,21, 32]. At this stage of the building completion, thermal performance defects (e.g. discontinuity of insulation layer or ruptures in the vapour barrier) cannot be easily identified with a visual inspection and require specialist tests (e.g. thermographic imaging or air tightness tests) [40, $43,85]$. Therefore, it is essential that these hidden defects (e.g. missing cavity closer) are promptly identified during the construction phase, when works can be observed before they are covered up or new works or trades start. At that point, the rework required is still possible and has a smaller impact on the project budget and schedule of works $[23,45,70]$ than if the problem is covered, the building is finished and/or occupied. The most frequent defects related to thermal performance mentioned in the literature are poor installation of insulation elements, gaps in the building's fabric and thermal bridging through structural elements, manifesting themselves in the buildings' envelope. These were identified by studies specifically focused on the impact of defects on the building energy performance [2, 40, 75]. Interestingly, other studies included in the review, not specifically focused on energy related issues (e.g. [20, 21, 63]) found that the most frequent defect types during the construction phase were incorrect installation and missing item, occurring most frequently in external walls, partitions, closure components (doors and windows), floors and roofs. Not being the focus of the studies, the link of these findings to the building thermal performance was not established, however they confirmed the recurrence of quality issues in the buildings envelope and fabric, which could indeed have an impact on the thermal performance. However, in those studies, this impact was overlooked.

In respect to the major causes leading to defects, the findings from both streams of studies (energy related defects and general defects) are similar. The findings suggest that the most frequent origin of defects are related to change, error, omission and damage occurring due to poor workmanship and design and inefficient management [17, 75, 83]. With the aim to reduce workmanship defects, construction companies should consider providing appropriate training to the trades to increase their awareness on the impact of the quality of their work on the building thermal performance, making use of photographic tools of those defects more likely to happen and how to avoid them. An example of this practice is the recently published Builders' Book by the Zero Carbon Hub [84], which highlights key construction details that require special care and helps builders improve site processes to deliver better performing homes and reduce the risk of condensation and mould growth, excessive heat loss and failure to meet building regulations. With regards to improving design and management in order to achieve the predicted building energy performance, the addition of an Energy Champion in the project team should be considered. This stakeholder would be appointed to monitor the project progress to ensure ongoing compliance with the relevant energy performance targets, during the design and construction, handover and close out stages [11]. 
The impact of quality defects on the building energy performance has been acknowledged in previous studies, mostly in relation to those defects affecting the thermal behaviour of the buildings' envelope which contributes to an increased heat loss [17, 82]. According to the reviewed studies the most recognised heat loss mechanisms are thermal bridging (e.g. high transmissivity of structural elements through the fabric), undesired increases of thermal transmittance (e.g. discontinuity of insulation layer) and unexpected air permeability (e.g. gaps in the air barrier) [7, 40,43]. Each one of them are related to quality defects originating in the design and construction process or linked to the decay of the buildings' envelope properties overtime. Some studies claim that the diverse types of defects affect the thermal performance in different levels $[42,45]$. However, there seems to be scarce information in terms of quantifying which type of defect has greater impact in the building energy use, both in relation to the actual contribution to heat loss and in respect to the frequency of occurrence in construction projects. In fact, at one end there are punctual studies aiming to quantify the heat loss caused by specific defects through simulation and modelling $[2,86]$. At the other end, there are studies which determine the overall heat loss or the whole building air leakage [13, 79]. Further studies that investigate the information which lies between these two extremes is still required if appropriate preventive measures to avoid defects affecting the buildings' thermal performance are to be developed and implemented. As recommended by ISO 9001:2015 [88], the prerequisite for a reliable and effective quality plan is to fully understand the type of non-conformances which may occur and prioritise the prevention of defects according to their impact on the designed performances of a project. Finally, efforts to avoid defects in construction projects are still required if the industry seeks to improve not only energy performance of the buildings, but also reduce costs, reduce delays, increase customer satisfaction and the overall industry reputation [7, 16, 73].

\section{Conclusion}

This review has highlighted the importance of preventing quality defects if construction projects aim to achieve, at the operational phase, the building energy performance intended at the design phase. The review has also identified the shortage of studies and sufficient information to provide a full understanding of the defects origin mechanisms and their impacts on the energy consumption of buildings, which in turn allows the development of effective quality plans and preventive measures.

The review has identified areas of knowledge where more research is needed towards achieving the designed standards of thermal performance in buildings. The authors suggest that future research should seek to explore the following topics:

- Defect classification system which provides a methodology for defect identification and collection, allowing the comparison of results from distinct studies in terms of type of defects and their frequencies. This area of research should also aim to promote the development of defect taxonomy, determining the defects' origin and sources, which in turn would aid the development of quality management programmes and the most needed upskilling of the design teams and on-site workforce. 
- Quantification of frequency of occurrence and the impact of different types of defects on the building's heat loss (through simulation/modelling and through real life case studies). The results should allow the development of quality management programmes which prioritise the mitigation of certain defects rather than others based on their potential to impair the thermal performance of buildings.

In addition, future investigations should also explore ways to increase energy performance awareness amongst clients, project teams and workforce. The inclusion of energy performance indicators among the other project indicators or the deployment of an energy champion in the project team is pivotal to trigger the proper measures to tackle the lack of literacy during the design process, increase the frequency of the monitoring of these energy performance criteria, and ultimately improve the quality of workmanship.

\section{Acknowledgements}

The work reported in this paper has been funded by the Brazilian Ministry of Science, Technology and Innovation through the Science without Borders research programme (Project reference:

203105/2014-1).

\section{References}

[1] IEA. FAQs: Energy Efficiency. 〈http://www.iea.org/aboutus/faqs/energyefficiency/〉 (accessed 10.07.14). http://www.iea.org/aboutus/faqs/energyefficiency/: International Energy Agency; 2016.

[2] Aïssani A, Chateauneuf A, Fontaine JP, Audebert P. Quantification of workmanship insulation defects and their impact on the thermal performance of building facades. Applied Energy. 2016;165:272-84.

[3] Jones RV, Fuertes A, Lomas KJ. The socio-economic, dwelling and appliance related factors affecting electricity consumption in domestic buildings. Renewable and Sustainable Energy Reviews. 2015;43:901-17.

[4] Buyle M, Braet J, Audenaert A. Life cycle assessment in the construction sector: A review. Renewable and Sustainable Energy Reviews. 2013;26:379-88.

[5] NEF. Insights from Social Housing Projects - Building Performance Evaluation Meta-Analysis. Executive Report Innovate UK: National Energy Foundation; 2016.

[6] Cohen R, Bordass B. Mandating transparency about building energy performance in use. Building Research \& Information. 2015;43:534-52.

[7] Palmer J, Godoy-Shimizu D, Tillson A, Mawditt I. Building Performance Evaluation Programme: Findings from domestic projects - Making reality match design. Innovate UK; 2016.

[8] AECOM. CEW1005 The Performance Gap - Non Domestic Building - Final Report. 2012.

[9] Carbon Trust. Closing the Gap: Lessons Learned on Realising the Potential of Low Carbon Building Design. Carbon Trust, London; 2011.

[10] Zero Carbon Hub. Carbon Compliance for Tomorrow's New Homes, A Review of the Modelling Tool and Assumptions, Topic 4, Closing the Gap Between Designed and Built Performance. 2010.

[11] Zero Carbon Hub. Closing the gap between design and as-built performance, End of term report. 2014.

[12] Menezes AC, Cripps A, Bouchlaghem D, Buswell R. Predicted vs. actual energy performance of non-domestic buildings: Using post-occupancy evaluation data to reduce the performance gap. Applied Energy. 2012;97:355-64.

[13] Bell M, Wingfield J, Miles-Shenton D, Seavers J. LowCarbon Housing: Lessons from Elm Tree Mews. Joseph Rowntree Foundation, York; 2010.

[14] de Wilde P. The gap between predicted and measured energy performance of buildings: A framework for investigation. Automation in Construction. 2014;41:40-9.

[15] Tofield B. Delivering a Low-Energy Building: Making Quality Common Place. (Build with CaRe report). University of East Anglia, Norwich; 2012.

[16] CIOB. What's happening to our quality control? Magazine of the Chartered Institute of Building.

http://www.constructionmanagermagazine.com/agenda/whats-happe7ning-our-qu6ality-co9ntrol/2016. 
[17] Gorse C, Stafford A, Shenton DM, Johnston D, Sutton R, Farmer D, et al. Thermal performance of buildings and the management process. Procs28th annual ARCOM conference2012. p. 3-5.

[18] Atkinson AR. The pathology of building defects; a human error approach. Engineering Construction \& Architectural Management (Wiley-Blackwell). 2002;9:53-61.

[19] Kylili A, Fokaides PA, Lopez Jimenez PA. Key Performance Indicators (KPIs) approach in buildings renovation for the sustainability of the built environment: A review. Renewable and Sustainable Energy Reviews. 2016;56:906-15.

[20] Forcada N, Macarulla M, Gangolells M, Casals M. Assessment of construction defects in residential buildings in Spain. Build Res Inf. 2014;42:629-40.

[21] Macarulla M, Forcada N, Casals M, Gangolells M, Fuertes A, Roca X. Standardizing Housing Defects: Classification, Validation, and Benefits. Journal of Construction Engineering \& Management. 2013;139:968-76.

[22] Auchterlounie T. Recurring quality issues in the UK private house building industry. Structural Survey. 2009;27:241-51.

[23] Sommerville J. Defects and rework in new build: an analysis of the phenomenon and drivers. Structural Survey.

2007;25:391-407.

[24] Ilozor BD, Okoroh MI, Egbu CE, Archicentre. Understanding residential house defects in Australia from the State of Victoria. Building and Environment. 2004;39:327-37.

[25] Davis K, Ledbetter WB, Burati Jr JL. Measuring design and construction quality costs. Journal of Construction Engineering and Management. 1989;115:385-400.

[26] Burati JL, Farrington JJ, Ledbetter WB. CAUSES OF QUALITY DEVIATIONS IN DESIGN AND CONSTRUCTION. J Constr Eng M Asce. 1992;118:34-49.

[27] ISO. ISO 9000:2005 - Quality Management Principles. Geneva, Switzerland2005.

[28] Georgiou J, Love PED, Smith J. A comparison of defects in houses constructed by owners and registered builders in the Australian State of Victoria. Structural Survey. 1999;17:160-9.

[29] Watt D. Building pathology : principles and practice. 2nd ed. ed. Oxford: Oxford : Blackwell; 2007.

[30] Mills A, Love PED, Williams P. Defect Costs in Residential Construction. J Constr Eng M Asce. 2009;135:12-6.

[31] Silvestre JD, de Brito J. Ceramic tiling in building façades: Inspection and pathological characterization using an expert system. Construction and Building Materials. 2011;25:1560-71.

[32] Forcada N, Macarulla M, Gangolells M, Casals M. Handover defects: comparison of construction and post-handover housing defects. Building Research \& Information. 2015:1-10.

[33] Forcada N, Macarulla M, Fuertes A, Casals M, Gangolells M, Roca X. Posthandover Housing Defects: Sources and Origins. Journal of performance of constructed facilities. 2013;27:756-62.

[34] Forcada N, Macarulla M, Love PED. Assessment of Residential Defects at Post-Handover. J Constr Eng M Asce. 2013;139:372-8.

[35] Forcada N, Macarulla M, Fuertes A, Casals M, Gangolells M, Roca X. Influence of Building Type on Post-Handover Defects in Housing. Journal of Performance of Constructed Facilities. 2012;26:433-40.

[36] Josephson PE, Larsson B, Li H. Illustrative benchmarking rework and rework costs in Swedish construction industry. Journal of Management in Engineering. 2002;18:76-83.

[37] Josephson PE, Hammarlund Y. The causes and costs of defects in construction: A study of seven building projects. Automation in Construction. 1999;8:681-7.

[38] Hansford P. SOLID WALL INSULATION - Unlocking Demand and Driving Up Standards. Green Construction Board and HM Government; 2015.

[39] Davis R, Wilen A, Crane T, Bryer L, Ward D, Pottier F, et al. UK Industry Performance Report - 2015. Construction Industry Key Performance Indicators2015.

[40] Johnston D, Miles-Shenton D, Farmer D. Quantifying the domestic building fabric 'performance gap'. Building Services Engineering Research and Technology. 2015.

[41] Pan W, Thomas R. Defects and Their Influencing Factors of Posthandover New-Build Homes. Journal of Performance of Constructed Facilities. 2015;29:04014119.

[42] Johnston D, Farmer D, Brooke-Peat M, Miles-Shenton D. Bridging the domestic building fabric performance gap. Building Research \& Information. 2014:1-14.

[43] Taylor T, Counsell J, Gill S. Combining thermography and computer simulation to identify and assess insulation defects in the construction of building façades. Energy and Buildings. 2014;76:130-42.

[44] Zero Carbon Hub. Closing the Gap Between Design and As-Built Performance - Evidence Review Report. 2014.

[45] Taylor T, Counsell J, Gill S. Energy efficiency is more than skin deep: Improving construction quality control in new-build housing using thermography. Energy and Buildings. 2013;66:222-31.

[46] Taylor T, Counsell J, Gill S, Oakley G. Assessing the severity of workmanship defects using thermography and 2-D and 3D heat transfer models. SB13 Graz Sustainable Building Conference. Graz, Austria: Verlag der Technischen Universität Graz; 2013.

[47] Wingfield J, Bell M, Miles-Shenton D, South T, Lowe R. Evaluating the impact of an enhanced energy performance standard on load-bearing masonry domestic construction - Understanding the gap between designed and real performance: lessons from Stamford Brook. 2011.

[48] Energy Saving Trust. Enhanced Construction Details: Thermal bridging and airtightness - CE302. 2009.

[49] Lowe RJ, Wingfield J, Bell M, Bell JM. Evidence for heat losses via party wall cavities in masonry construction. Build Serv Eng Res T. 2007;28:161-81.

[50] Sommerville J, McCosh J. Defects in new homes: an analysis of data on 1,696 new UK houses. Structural Survey. 2006;24:6-21.

[51] Bell M, Smith M, Miles-Shenton D. Condensation Risk - Impact of Improvements to Part L And Robust Details On Part C Interim Report Number 7: Final Report on Project Fieldwork, Report to the ODPM Building Regulations Division under the 
Building Operational Performance Framework - Project Reference Number Cl 71/6/16 (BD2414). Leeds Metropolitan University, Leeds, UK.; 2005. p. 84.

[52] Sommerville J, Craig N, Bowden S. The standardisation of construction snagging. Structural Survey. 2004;22:251-8. [53] Bordass B, Cohen R, Standeven M, Leaman A. Assessing building performance in use 2: technical performance of the Probe buildings. Build Res Inf. 2001;29:103-13.

[54] Harrison H. Quality in new-build housing: Building Research Establishment Watford, UK; 1993.

[55] Bresnen M, Haslam C, Beardsworth A, Bryman A, Keil E. Performance on site and the building client: The Chartered Institute of Building; 1990.

[56] Bonshor RB, Harrison HW. Traditional housing: A BRE study of quality: Building Research Establishment Watford, UK; 1982.

[57] Aljassmi H, Han S, Davis S. Project Pathogens Network: New Approach to Analyzing Construction-Defects-Generation Mechanisms. Journal of Construction Engineering and Management. 2014;140:04013028.

[58] Georgiou J. Verification of a building defect classification system for housing. Structural Survey. 2010;28:370-83.

[59] Love PED, Edwards DJ. Forensic project management: The underlying causes of rework in construction projects. Civil Engineering and Environmental Systems. 2004;21:207-28.

[60] Love PED. Influence of project type and costs in building procurement method on rework construction projects. J Constr Eng M Asce. 2002;128:18-29.

[61] Love PED, Li H. Quantifying the causes and costs of rework in construction. Construction Management \& Economics. 2000;18:479-90.

[62] Palaneeswaran E, Ramanathan M, Tam C. Rework in projects: Learning from errors. Surveying and Built Environment. 2007;18:47-58.

[63] Abdul-Rahman H, Wang C, Wood LC, Khoo YM. Defects in Affordable Housing Projects in Klang Valley, Malaysia. Journal of Performance of Constructed Facilities. 2014;28:272-85.

[64] Hwang B-G, Zhao X, Goh KJ. Investigating the client-related rework in building projects: The case of Singapore. International Journal of Project Management. 2014;32:698-708.

[65] Hwang BG, Thomas SR, Haas CT, Caldas CH. Measuring the Impact of Rework on Construction Cost Performance. J Constr Eng M Asce. 2009;135:187-98.

[66] Chong W, Low S. Latent Building Defects: Causes and Design Strategies to Prevent Them. Journal of Performance of Constructed Facilities. 2006;20:213-21.

[67] Chong W, Low S. Assessment of Defects at Construction and Occupancy Stages. Journal of Performance of Constructed Facilities. 2005;19:283-9.

[68] Wanberg J, Harper C, Hallowell MR, Rajendran S. Relationship between Construction Safety and Quality Performance. Journal of Construction Engineering and Management. 2013;139:04013003.

[69] Barber P, Graves A, Hall M, Sheath D, Tomkins C. Quality failure costs in civil engineering projects. International Journal of Quality \& Reliability Management. 2000;17:479-92.

[70] Love PED, Edwards DJ. Curbing rework in offshore projects: systemic classification of risks with dialogue and narratives. Structure and Infrastructure Engineering. 2012;9:1118-35.

[71] Battikha MG. Reasoning mechanism for construction nonconformance root-cause analysis. J Constr Eng M Asce. 2008;134:280-8.

[72] Fayek AR, Dissanayake M, Campero O. Developing a standard methodology for measuring and classifying construction field rework. Canadian Journal of Civil Engineering. 2004;31:1077-89.

[73] Jafari A, Love PED. Quality Costs in Construction: Case of Qom Monorail Project in Iran. Journal of Construction Engineering and Management. 2013;139:1244-9.

[74] Oyewobi L, Oke A, Ganiyu B, Shittu A, Isa R, Nwokobia L. The effect of project types on the occurrence of rework in expanding economy. Journal of Civil Engineering and Construction Technology. 2011;2:119-24.

[75] Wang Q, Augenbroe G, Sun Y. The role of construction detailing and workmanship in achieving energy efficient buildings. Construction Research Congress, Atlanta, May2014. p. 19-24.

[76] BPIE. Europe's Buildings under the microscope: A country-by-country review of the energy performance of buildings: Buildings Performance Institute Europe (BPIE); 2011.

[77] Egan J. The Egan Report-Rethinking Construction. Report of the Construction Industry Task Force to the Deputy Prime Minister London. 1998.

[78] Love PE, Edwards DJ. Determinants of rework in building construction projects. Engineering, Construction and Architectural Management. 2004;11:259-74.

[79] Kalamees T. Air tightness and air leakages of new lightweight single-family detached houses in Estonia. Building and Environment. 2007;42:2369-77.

[80] Ahzahar N, Karim NA, Hassan SH, Eman J. A Study of Contribution Factors to Building Failures and Defects in Construction Industry. Procedia Engineering. 2011;20:249-55.

[81] Aiyetan A. Causes of rework on building construction projects in Nigeria. Interim: Interdisciplinary Journal. 2013;12:1-15. [82] van Dronkelaar C, Dowson M, Spataru C, Mumovic D. A Review of the Regulatory Energy Performance Gap and Its Underlying Causes in Non- domestic Buildings. Front Mech Eng. 2016;1.

[83] Zero Carbon Hub. Thermal Bridging Guide. www.zerocarbonhub.org2016.

[84] Zero Carbon Hub. Builders' Book - An illustrated guide to building energy efficient homes. www.zerocarbonhub.org2015.

[85] Hopper J, Littlewood JR, Taylor T, Counsell JAM, Thomas AM, Karani G, et al. Assessing retrofitted external wall insulation using infrared thermography. Structural Survey. 2012;30:245-66.

[86] Na R, Lin SM, Gu LX, Grosskopf K, Shen ZG. IMPACT OF AIR LEAKAGE THROUGH RECESSED LIGHTING FIXTURES ON THE ENERGY PERFORMANCE OF RESIDENTIAL BUILDINGS - A CASE STUDY2013. 
[87] Hoonakker P, Carayon P, Loushine T. Barriers and benefits of quality management in the construction industry: An empirical study. Total Qual Manag Bus. 2010;21:953-69.

[88] BSI. BS EN ISO 9001:2015. Quality management systems Requirements: British Standards Institution; 2015. 